\title{
COMPLEX APPROACH TO ASSESSMENT OF INVESTMENT ATTRACTIVENESS OF POWER GENERATING COMPANY
}

\author{
V.G. Mokhov ${ }^{1}$, G.S. Chebotareva ${ }^{2}$, T.S. Demyanenko ${ }^{1}$ \\ ${ }^{1}$ South Ural State University, Chelyabinsk, Russian Federation \\ ${ }^{2}$ Ural Federal University, Ekaterinburg, Russian Federation \\ E-mail: mokhov50@mail.ru, g.s.chebotareva@urfu.ru,oop_flp@mail.ru
}

\begin{abstract}
Present approaches based on the qualitative analysis methods are not effective enough for a comprehensive evaluation of the investment attractiveness of the power generating company (PGC). It resolves the urgency of the complex deterministic method of accounting for aggregated risk. The article presents the diagnostics of power generating company risks' and the assessment of the actual aggregated risk as the integral indicator of investment attractiveness of the PGC. The proposed authors' approach to ranking the risk taking into account the level of hazard is based on the calculation of individual limits of risk states variation and risk relative value. The individual risk assessment is based on the Bayes method complemented by a two-step normalization to account for the specificity of PGC. The Merton - Vasicek method and basic principles of the economic capital theory are used in developing the method of the final evaluation of the PGC investment attractiveness. Research veracity is confirmed by the practical implementation. The research results are recommended for use in assessing the current level of the PGC investment attractiveness and development strategy of its increase.
\end{abstract}

Keywords: investments attractiveness; power generating company; risk; Bayes method; theory of economic capital; Merton - Vasicek method.

The challenges facing the energy at the present stage require industry to transit to a new higher level maximally contributing to the dynamic social and economic development [1]. However, the high demand for renovation is accompanied by a limitation of capital investment including the sanctions of the EU. It makes a very important problem of improving the investment attractiveness of the energy companies. Up to the present time there are no objective formalized approaches to assessment of investment attractiveness of the companies in the Russian energy sector and effective tools for the management of specific risks are in the initial stage of development [1].

The theory for the development of this complex approach to assessment of investment attractiveness of PGC is based on the hypothesis of completeness of the PGC' investment attractiveness description through the power company risks [1] and observance of the principle of objective assessment [2].

1. Risk ranking identifies the most dangerous risks that troubled the normal development of the PGC. It is possible due to the two-step risk normalization based on the method of linear scaling according to the following equations for indicators of direct and inverse relations respectively:

$$
\begin{aligned}
& X_{j}^{H}=\frac{X_{j}-X_{\min }}{X_{\max }-X_{\min }} \cdot 90^{\circ}, \\
& X_{j}^{H}=\frac{X_{\max }-X_{j}}{X_{\max }-X_{\min }} \cdot 90^{\circ},
\end{aligned}
$$


where $X_{j}^{H}$ is actual normalized value of the $j$-th risk; $X_{j}$ is actual value of the $j$-th risk; $X_{\min }$ is minimum actual value of the $j$-th risk; $X_{\max }$ is maximum actual value of the $j$-th risk; factor $90^{\circ}$ is introduced for graphical interpretation purposes.

Individual assessment of risk involves the calculation of the individual limits of risk states variation, which is based on Bayes method:

$$
\begin{gathered}
\ln \left(c_{i} \cdot q_{i}\right)-0,5 \cdot\left(\left(X-M_{i}\right)^{T} \cdot S_{i}^{-1} \cdot\left(X-M_{i}\right)-\ln \left|S_{i}\right|\right)-\left(\ln \left(c_{i+1} \cdot q_{i+1}\right)-\right. \\
\left.-0,5 \cdot\left(\left(X-M_{i+1}\right)^{T} \cdot S_{i+1}^{-1} \cdot\left(X-M_{i+1}\right)-\ln \left|S_{i+1}\right|\right)\right)=0
\end{gathered}
$$

where $\mathrm{X}$ is the risk in the space of risks under study; $M_{i}, M_{i+1}$ are the expectation values of the $i$-th and the $(i+1)$-th states; $S_{i}, S_{i+1}$ are the covariance matrices of the $i$-th and the $(i+1)$-th states; $q_{i}, q_{i+1}$ are the prior occurrence probabilities for the $i$-th and the $(i+1)$-th objects; $c_{i}, c_{i+1}$ are the costs of error in the reference of objects to the $i$-th and the $(i+1)$-th states.

The resulting risks' rating is the basis for complex analysis of the actual aggregated risk, which integrates into a single indicator the values of the identified risks. Graphical interpretation of the aggregated risk involves the location of risks in ascending order of its influence level on the investment attractiveness of PGC. The example of this graphical interpretation is presented in Figure. It is the result of analysis of the investment attractiveness of the power company JSC "T Plus" in accordance to the "neutral" scenario.

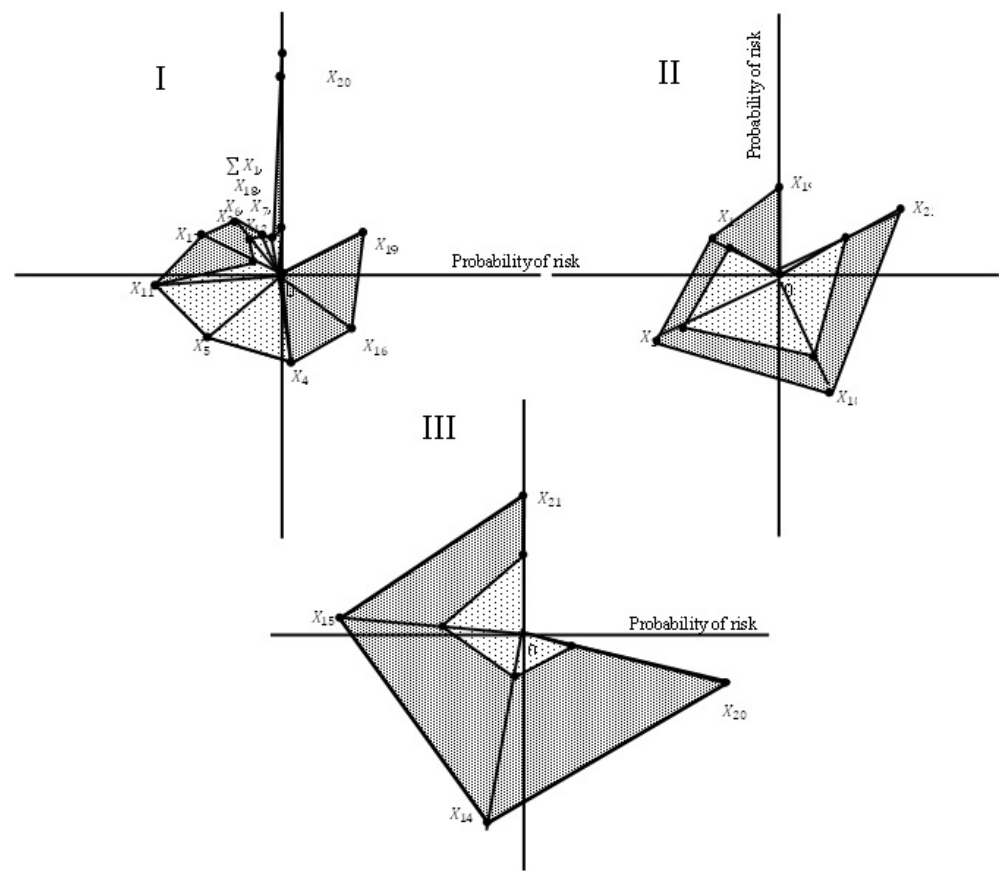

Graphical interpretation of the aggregated risk (JSC "T Plus" with "neutral" scenario)

Evaluation of the actual aggregated risk is based on the analysis of graphical interpretation and is calculated as the average value between the maximum and minimum amounts of the aggregated risk according to the following equation:

$$
R=\frac{\sum_{j=1}^{n}\left(p_{j}^{\max } \cdot p_{j+1}^{\max } \cdot \sin \gamma_{j+1}\right)+p_{1}^{\max } \cdot p_{n}^{\max } \cdot \sin \gamma_{1}}{4}+\frac{\sum_{j=1}^{n}\left(p_{j}^{\min } \cdot p_{j+1}^{\min } \cdot \sin \gamma_{j+1}\right)+p_{1}^{\min } \cdot p_{n}^{\min } \cdot \sin \gamma_{1}}{4}
$$

where $\mathrm{R}$ is actual value of aggregated risk; $p_{j}^{\max }$ is maximum of the $j$-th risk probability; $p_{j+1}^{\max }$ is maximum of the $(j+1)$-th risk probability; $p_{j}^{\min }$ is minimum of the $j$-th risk 
probability; $p_{j+1}^{\min }$ is minimum of the $(j+1)$-th risk probability; $\gamma_{j+1}$ is the $(j+1)$-th risk level of influence on investment attractiveness of PGC; $n$ is the number of risks under study;

$$
\frac{1}{2} \cdot\left[\sum_{j=1}^{n}\left(p_{j}^{\max } \cdot p_{j+1}^{\max } \cdot \sin \gamma_{j+1}\right)+p_{1}^{\max } \cdot p_{n}^{\max } \cdot \sin \gamma_{1}\right]=R^{\max }
$$

is the maximum aggregated risk value;

$$
\frac{1}{2} \cdot\left[\sum_{j=1}^{n}\left(p_{j}^{\min } \cdot p_{j+1}^{\min } \cdot \sin \gamma_{j+1}\right)+p_{1}^{\min } \cdot p_{n}^{\min } \cdot \sin \gamma_{1}\right]=R^{\min }
$$

is the minimum aggregated risk value.

2. Final evaluation of investment attractiveness includes the calculation of threshold value of aggregated risk by equation which takes into account the basic principles of economic capital theory:

$$
R_{\text {threshold }}=R \cdot\left(1-\frac{\Delta C R}{C R_{\text {actual }}}\right),
$$

where $R_{\text {threshold }}$ is a threshold value of aggregated risk; $\mathrm{R}$ is actual value of aggregated risk; $\Delta C R=C R_{\text {req }}-C R_{\text {actual }} ; C R_{\text {req }}$ is a required by the PGC economic capital; $C R_{\text {actual }}$ is the value of $\mathrm{PGC}$ net wealth.

Calculation of the initial values of required by PGC economic capital is carried out by Merton - Vasicek method [3]:

$$
C a R_{r e q}=E A D \cdot L G D \cdot\left(N\left(\frac{N^{-1}(P D)+N^{-1}(\alpha) \cdot \sqrt{r}}{\sqrt{1-r}}\right)-P D\right),
$$

where $C a R_{r e q}$ is the initial required by PGC economic capital; EAD is exposure at default; LGD is PGC loss given default; $\mathrm{N}()$ is standard normal distribution; $N^{-1}()$ is inverse standard normal distribution; PD is PGC probability of default; $\alpha$ is reliability level; $r$ is a coefficient of correlation between PGC state and state of region economy.

In case of exceeding of the duration of the investment phase of the project for more than one year it requires the correction of the CaR by the amount of risk horizon [4]:

$$
C R_{r e q}=C a R_{r e q} \cdot M,
$$

where $C R_{r e q}$ is the required by PGC economic capital including fee of exceeding the duration of the investment phase; $M$ is maturity [5].

The estimated indicators in equations (8) and (9) correspond to the following conditions:

$$
\left\{\begin{array}{l}
P D=\sum_{j=1}^{n}\left(p_{j}^{\text {aver }} \cdot \gamma_{j}^{\text {share }}\right), \\
r=\frac{\operatorname{cov}\left(p_{j e x}^{\text {aver }} \cdot p_{j e n d}^{\text {aver }}\right)}{\sigma_{p_{\text {jex }}^{\text {aver }}} \cdot \sigma_{p_{j e n d}^{\text {aver }}}} \\
M=\frac{1+T-2,5 \cdot b(P D)}{1-1,5 \cdot b(P D)}
\end{array}\right.
$$

where $p_{j}^{\text {aver }}$ is the average probability of the $j$-th risk; $\gamma_{j}^{\text {share }}$ is the share of influence level of the $j$-th risk on investment attractiveness; $\operatorname{cov}\left(p_{j e x}^{\text {aver }} \cdot p_{\text {jend }}^{\text {aver }}\right)$ is the covariance value of indicators $p_{j e x}^{a v e r}$ and $p_{j e n d}^{a v e r} ; \sigma_{p_{j e x}^{a v e r}}$ and $\sigma_{p_{j e n d}^{a v e r}}$ are the standard deviations of $p_{j e x}^{a v e r}$ and $p_{j e n d}^{a v e r}$; 
$p_{\text {jex }}^{\text {aver }}$ and $p_{\text {jend }}^{\text {aver }}$ are the average values of the $j$-th exogenous and the $j$-th endogenous risk probability; $T$ is the duration of project investment phase;

$$
\text { factorb }(P D)=(0,00852-0,05489 \cdot \ln (P D))^{2} \text {. }
$$

The quantitative assessment of the level of PGC investment attractiveness is possible by the way of comparison of actual and threshold values of aggregated risk:

$$
\Delta R_{\text {final }}=R-R_{\text {threshold }}
$$

where $\Delta R_{\text {final }}$ is the amount of PGC investment attractiveness.

When the value $\Delta R_{\text {final }}>0$, the PGC is not attractive for investors. This value indicates the "excessive" amount of risk which needs to be minimized. In the opposite situation PGC is attractive. The formed difference shows the amount of "financial reserve" for risks the company has.

Conclusion. 1. A topical problem of deterministic assessment of PGC investment attractiveness is solved. 2. The results are recommended for use in the development of risk-management program in PGC. 3. The developed method of deterministic assessment of PGC aggregated risk allows to increase its openness and investment attractiveness.

Acknowledgements. The work was supported by Act 211 Government of the Russian Federation, contract No. 02.A03.21.0011.

\title{
References
}

1. Domnikov A., Chebotareva G., Domnikova L. Economic and Technological Priorities of Competitive Development of Russian Systems of Energy Cogeneration Sources. International Journal of Design and Nature and Ecodynamics, 2016, vol. 11, no. 4, pp. 610-619. DOI: $10.2495 /$ DNE-V11-N4-610-619

2. Proposed Enhancements to the Basel II Framework (2014). Available at: www.bis.org (accessed 10 January 2017)

3. Shiryaev A.N. Fundamentals of Stochastic Financial Mathematics. Moscow, MCNMO, 2016. $440 \mathrm{p}$.

4. Shevelev A.E., Sheveleva E.V. Risks in Accounting. Moscow, KnoRus, 2015. 304 p.

5. Simchera V.M. Methods of Multivariate Analysis of Statistical Data. Moscow, Finance and Statistics, 2008. 400 p.

Received March 6, 2017

УДК 330.322.013+001.895

DOI: $10.14529 / \mathrm{mmp} 170213$

КОМПЛЕКСНЫЙ ПОДХОД К ОЦЕНКЕ ИНВЕСТИЦИОННОЙ ПРИВЛЕКАТЕЛЬНОСТИ ЭНЕРГОГЕНЕРИРУЮЩЕЙ КОМПАНИИ

\author{
В.Г. Мохов ${ }^{1}$, Г.С. Чеботарева ${ }^{2}$, Т.С. Демъяненко \\ ${ }^{1}$ Южно-У ральский государственный университет, г. Челябинск \\ ${ }^{2}$ У ральский федеральный университет, г. Екатеринбург
}

Современные подходы, основанные на качественных методах анализа, недостаточно эффективны для всесторонней оценки инвестиционной привлекательности 
энергогенерирующей компании (ЭГК). Это предопределило актуальность разработки комплексного детерминированного метода учета совокупного риска. Статья посвящена диагностике состояния рисков развития энергогенерирующей компании и оценке фактического совокупного риска в качестве интегрального показателя инвестиционной привлекательности ЭГК. Предложен авторский подход к ранжированию рисков развития по уровню их опасности на основе расчета индивидуальных границ изменения состояний рисков и относительного значения каждого риска. При индивидуальной оценке рисков развития использован метод Байеса, дополненный двухэтапным нормированием для учета специфики ЭГК. При разработке метода итоговой оценки инвестиционной привлекательности ЭГК использован метод Мертона - Васичека и базовые принципы концепции экономического капитала. Достоверность результатов исследования подтверждена практической реализацией. Полученные результаты рекомендуются к использованию при оценке текущего состояния и разработке стратегии повышения инвестиционной привлекательности ЭГК.

Ключевые слова: инвестищионная привлекательность; энергогенерирующая компания; риски развития; метод Байеса; теория экономического капитала; метод Мертона - Васичека.

\section{Литература}

1. Domnikov, A. Economic and Technological Priorities of Competitive Development of Russian Systems of Energy Cogeneration Sources / A. Domnikov, G. Chebotareva, L. Domnikova // International Journal of Design and Nature and Ecodynamics. - 2016. - V. 11, № 4. P. 610-619.

2. Proposed Enhancements to the Basel II Framework (2014). - URL: www.bis.org (дата обращения: 10 января 2017 г.)

3. Ширяев, А.Н. Основы стохастической финансовой математики. Т. 1. Факты. Модели / А.Н. Ширяев. - М.: МЦНМО, 2016. - 440 с.

4. Шевелев, А.Е. Риски в бухгалтерском учете / А.Е. Шевелев, Е.В. Шевелева. - М.: КноPyc, 2015. - 304 c.

5. Симчера, В.М. Методы многомерного анализа статистических данных / В.М. Симчера.М.: Финансы и статистика, 2008. - 400 с.

Вениамин Геннадьевич Мохов, доктор экономических наук, профессор, кафедра «Экономика и управление на предприятиях сферы услуг, рекреации и туризма», Южно-Уральский государственный университет (г. Челябинск, Российская Федерация), mokhov50@mail.ru.

Галина Сергеевна Чеботарева, кандидат экономических наук, доцент, кафедра «Банковский и инвестиционный менеджмент», Уральский федеральный университет (г. Екатеринбург, Российская Федерация), g.s.chebotareva@urfu.ru.

Татьяна Сергеевна Демьяненко, старший преподаватель, кафедра «Математическое и компьютерное моделирование», Южно-Уральский государственный университет (г. Челябинск, Российская Федерация), оop_flp@mail.ru.

Поступила в редакцию 6 марта 2017 г. 